This is an Accepted Manuscript of an article published by Taylor \& Francis Group in Journal of Education and Work on 13 Feb 2020, available online: http://www.tandfonline.com/10.1080/13639080.2020.1722989.

\title{
Further education in the UK: lessons from the governance of colleges in Scotland
}

Cate Watson*, Gary Husband, and Helen Young

Faculty of Social Sciences, University of Stirling, Stirling, FK4 9LA

Corresponding author: cate.watson@stir.ac.uk

To appear in: Journal of Education and Work, 2020.

This document is the version accepted for publication, 25.01.20. 


\title{
Further education in the UK: lessons from the governance of colleges in Scotland
}

\begin{abstract}
Further education policy across the UK has diverged significantly over the last decade. While in both countries colleges have been subject to a programme of restructuring and rationalisation, Scotland now has a largely 'nationalised' sector while England has adopted a more market-led approach which has been characterised in some quarters as a 'free for all'. However, there are some signs that England is starting to turn away from this stance and it is therefore instructive to examine the influence of policy on the Scottish sector, particularly as England embarks on a programme of devolution to the regions. This paper draws on policy documents and interviews with key policy actors to examine the 'Scottish Approach' to policy and the effects of this on the performance of the sector. While this has undoubtedly resulted in a more coherent system it is argued that colleges have paid a price for this, foregoing much of their previous autonomy. Moreover, it is not clear that the approach has addressed the 'skills gap' as currently perceived. It is concluded that much can be learned by greater engagement across the border, informed by clearer understanding of how policy contexts impact on the leadership and governance of colleges.
\end{abstract}

\section{Keywords}

Colleges, governance, further and higher education, incorporation of colleges, outcome agreements, further education policy, regionalisation, skills, sociology of worth, training

\section{Introduction}


Further education (FE) in the UK occupies an unenviable and somewhat paradoxical position, marginalised and yet subject to almost constant political tinkering. Norris and Adam (2017) refer to this as policy churn saying,

The further education (FE) sector has been defined by more or less continuous change over the last three decades. Our timeline of major policy, programme, leadership and organisational changes in the sector demonstrates the sheer scale of churn that has been experienced.

While no part of the UK has been exempt from the external conditions which attend this state of churn, responses in Scotland have been very different from England (Payne 2009; Keep 2017). Indeed, Keep (2017) contrasts Scotland's further education 'system' with the free-forall that has hitherto characterised the sector in England. However, under the May Government (2017-2019) Spours et al $(2019,3)$ detected 'signs of a turn away from marketisation'. It is therefore instructive to examine further education in Scotland to arrive at an appreciation of the influence of policy context on the performance of the sector and to consider what lessons can be learned, particularly as England embarks on a programme of regional devolution.

The paper is structured as follows. First, we set out the historical context of current governance arrangements in Scotland's Colleges, pinpointing reclassification of colleges in 2011 as a decisive moment. We then examine the current governance framework, drawing on policy documents and interviews with key policy actors. From this analysis we identify four emergent contextual themes: identification within transnational policy spaces; positioning of the sector with respect to universities; tensions surrounding the 'skills agenda' and industry links; and finally, relations of governance within the sector. We end by considering the implications of this analysis for an appreciation of the current challenges and future 
orientation of further education within the UK and we call for a research agenda aimed at understanding the impact of policy contexts on leadership and governance of colleges.

\section{A recent history of the college sector in Scotland}

The further education sector in Scotland has undergone a period of significant restructuring over the past decade. This can be traced back to a pivotal moment in the governance of colleges in the UK brought about through the reclassification of colleges by the Office for National Statistics (ONS) in 2010 from Non-profit Institutions Serving Households (NPISH) to Central Government (CG) entities. NPISH, under EU regulations which define the accounting rules required for harmonisation (European System of Accounts95, Eurostat, nd), are organisations that are:

not mainly financed and controlled by government and which provide goods or services to households for free or at prices that are not economically significant. (eurostat, nd)

Colleges were held by the ONS to fail NPISH criteria on the basis of government powers over corporate policy in colleges, in particular a key test was a requirement for government consent to borrow funds (MacPherson 2013). Reclassification from NPISH to CG was backdated to 1993, the date at which colleges in Scotland and the rest of the UK had been taken out of local authority control and replaced by a Board of Management (referred to as 'incorporation') (Further and Higher Education (Scotland) Act 1992). While in England legislation was passed which removed public sector controls over colleges, in Scotland the controls were regarded as appropriate and hence reclassification was accepted. This marked a significant divergence of policy within the UK. Reclassification was required to be completed by 2014 . 
Though it was argued that the ONS pronouncement was both flawed and 'unwelcome' (Scottish Parliament 2014) nonetheless, reclassification provided the Minister (Mike Russell) with an opportunity to enact changes which extended government control of the sector. Following incorporation in 1993 and removal of colleges from local authority control, greater autonomy had given rise to individualisation and competition, and as a result the Scottish Government argued that 'the sector lacked the necessary accountability, coherence and direction to successfully engage with challenges of the future' (O'Donnell et al 2015, 60). Bringing the sector into central government control was further legitimated by a report critical of governance in some individual colleges and of aspects of college governance in general, including a need for better financial information to boards and improved risk management practices (Audit Scotland 2010).

Shortly after this, in 2011, the Minister announced a review of college governance to be chaired by Professor Russell Griggs ('Griggs Report', Scottish Government 2012a). The remit of the Griggs Report was two-fold. To assess:

a) How the sector as a whole should be managed across Scotland

b) Having decided that, how each College or entity should be governed. (1)

However, Griggs notes that even before the committee began its work, the Minister had already decided on a far-reaching, structural reorganisation of the sector which would see mergers of colleges along regional lines. The 'pre-proposal paper', Putting learners at the centre: delivering our ambitions for post-16 education (Scottish Government 2011); and a subsequent consultation paper College regionalisation: proposals for implementing putting learners at the centre (Scottish Government/Scottish Funding Council,2011) pre-empted Griggs and set out the Minister's thinking. As with all such 'nonsultations' these documents sought stakeholder feedback on issues that had already been decided. The rationale for this 
programme of regionalisation was explicitly located in the ONS reclassification decision, positioning Scotland as distinct from England, and claiming the moral high ground for this:

In Scotland, as elsewhere, an increasingly competitive global economy demands our people develop new and different skills. The financial difficulties we face as a result of the UK Government's contraction of public spending also means we have to make difficult decisions on how best to provide and deliver post-16 education in the future.

Our approach is to follow our own path, rejecting moves elsewhere in the UK for a wholesale transfer of the financial burden associated with learning from the state to the learner; instead, we want to deliver a unique Scottish solution. Our approach is one endorsed by the people of Scotland in their unequivocal decision to back our manifesto commitments. (Putting learners at the centre, Scottish Government 2011, 4)

The proposals claimed that the current system encouraged both duplication and unnecessary competition between colleges and that greater planning was required in order to 'strengthen the alignment between post-16 learning and jobs and growth' (45). Hence, benefits were to be achieved through 'federations, mergers or other innovative means'. Moreover, the paper argued that for the most part a regional basis for merger was warranted, enabling colleges to continue to be responsive to local needs.

That the Scottish Government saw moves to regionalisation as a means to exert more centralised control is evident in the proposed changes to governance, requiring enhanced accountability and, through the Scottish Funding Council (SFC), 'a more robust approach to performance management' (49). This left little for the Griggs committee to report on in terms 
of the proposed restructuring. Gamely, the committee adjusted its work to 'focus on what that outcome means'. In this light, Griggs emerges as a form of post-hoc justification of regionalisation to back up the 'solution-driven' sectoral reforms advanced by government. This did not stop Griggs taking the flak for the proposed changes. The Times Educational Supplement reported opposition among college principals,

If they are angry, hostile and worried about the future, it's easy to understand why. These people have worked hard since the incorporation of colleges in 1993 to run them as successful businesses catering for local needs and a changing workforce. Then along comes Professor Griggs who would like to see 'a Scottish plan' for things like shared services; 41 individual colleges merged into 12 regional ones; excess profits taken away from them; staff salaries decided nationally, and principals not even allowed to sit on the college board, on the grounds that they are employees. Suddenly, it's as if their businesses are being taken away from them and they are being 'punished', as one put it, for their success. (Macdonald 2012)

The Griggs report recommended: one college per region, except for the 'unique' University of the Highlands and Islands; an 'outcomes driven approach' in which funding would be linked to agreed outcomes to be monitored by the SFC (this led to the introduction of regional 'Outcome Agreements'); and that colleges should not be allowed to hold surpluses in excess of $10 \%$ of annual revenue. These recommendations were largely accepted (Scottish Government 2012b), although in the event two additional regions (Lanarkshire and Glasgow) emerged from the process as multi-college, for reasons that are not immediately apparent. The Griggs report created a further rationale for regionalisation, noting that a range of salary scales and governance procedures had given rise to inequalities across the 
system which had not benefited learners and hence also recommended a return to national bargaining.

The recommendations of the Griggs Review were heavily influenced by ONS reclassification. In imposing the SFC between government and colleges a potential clash between ONS reclassification and the retention of charitable status by colleges was averted since Ministerial control over charitable bodies is not permitted (Charities and Trustee Investment (Scotland) Act 2005). More fundamentally, ONS reclassification did not allow colleges to accumulate reserves (even to the extent recommended by Griggs). In relation to this, the Auditor General wrote:

Colleges will now have to operate within an annual budget which reflects their income and expenditure, including Scottish Government funding. Colleges will still be able to spend income which they generate from other sources within the same financial year. However, their net expenditure must avoid creating a surplus or deficit within Scottish Government budget control limits. As a result, the change in colleges' status means that access to accumulated reserves at the point of reclassification, and the ability of colleges to generate and use future surpluses, will be constrained ${ }^{1}$. (Audit Scotland 2013, 33)

Colleges were thus required to deposit surpluses, at year's end, in 'Arm's Length Foundations', to which they and other organisations, could apply for access, a requirement with consequent implications for longer term strategic planning and overall sense of autonomy. 
In relation to governance, Griggs recommended that the Chair of a regional college board should be endorsed by the Minister and remunerated 'in the same manner as Chairs of some other public entities' (5). The government response to Griggs (Scottish Government 2012b) proposed that assigned colleges (constituents of multi-college regions) would have smaller boards, responsible for operational matters. These would be chaired by the college Principal, accountable to a regional board. This latter stipulation has not been followed, based as it was on an assumption that assigned colleges would be smaller than regional colleges, which has not been borne out. Indeed, City of Glasgow, an assigned college within the Glasgow Region, exceeds all other regional colleges in size and complexity and brands itself a 'supercollege'.

Forty-three incorporated colleges were reduced to 26 following regionalisation and 13 regions were created. Although the Minister 'firmly believed' that it was for colleges to work together in determining mergers 'in the best interests of learners' it was claimed that some degree of control was exercised through Ministerial selection of regional leads to take the process forward (Belgutay 2012, cited in McPherson 2013). Though the process is now largely complete, the reverberations are still being felt in the sector. In particular, the return to collective bargaining gave rise to a sustained period of industrial unrest which was only settled in 2019.

In 2014 a Code of Good Governance for Scotland's Colleges was developed and an amended version released in 2016 (Scotland's Colleges 2016). This adopts the principle, familiar in corporate codes of good governance, 'comply or explain'. A consultation on governance to further amend the code was launched in 2017. The most contentious aspect of this was a proposal to include trades union representatives on the board. Though those responding to the 
consultation were largely against this (Scottish Government 2019), the proposal has been adopted and two representatives of trades unions will sit on regional boards from 2020.

This is the context in which the research for this paper was conducted. Curiously, in this instance, regionalisation - which normally refers to a process of decentralisation and greater local autonomy - has meant a return of control to the centre. This nationalisation of the sector (as several of our interviewees referred to it) does not, however, indicate a return to old-fashioned Labour ideology of the 1960s. Rather, it represents a turn to an 'inclusive liberalism' (Porter and Craig 2004) which seeks to secure the gains of the neoliberalised order while mitigating some of its socially disaggregating effects. Thus, inclusive liberalism embraces concerns around security, risk and particularly the participation of marginalised subjects: 'whereas a previous neo-liberalism would have left them to sink or swim in the frank market, “inclusive” liberalism won't let them get away so easily' (Porter and Craig 2004, p.392).

\section{This study}

This study forms part of a larger research project examining governing boards in colleges of further education in the UK (Watson, 2020). For this piece senior policy actors in key organisations concerned with the governance of further education in Scotland were interviewed and asked about: the role of their respective organisation and their relationship with colleges; their perspectives on the further education sector in Scotland (current challenges/future prospects); impact of recent policy changes; and their thoughts around governance of the sector. Interviews were audio recorded and transcribed. Transcriptions were returned to interviewees for verification and points of clarification. Key themes were identified and traced through the policy framework. 
Interviews were conducted with senior policy actors in:

Scottish Government (2 interviewees);

College Senior Management (3 interviewees);

Enterprise and Skills Strategic Board (1 interviewee). ESSB was created in November 2017.

Its objective is to align and co-ordinate the activities of Scotland's enterprise and skills agencies: Scottish Enterprise, Highlands and Islands Enterprise, Skills Development

Scotland, South of Scotland Economic Partnership; and the Scottish Funding Council. https://www.gov.scot/groups/enterprise-and-skills-strategic-board/;

Scottish Funding Council (1 interviewee). SFC is a Non-Departmental Public Body of the Scottish Government. It is the conduit providing funding to Scotland's colleges and universities. http://www.sfc.ac.uk/;

Colleges Scotland ( 2 interviewees). CS is 'the collective voice of the college sector in Scotland; striving to create cohesive and sustainable partnerships, demonstrate positive impact, acting as representatives, and campaigning for the sector'. $\underline{\text { https://collegesscotland.ac.uk/ }}$

College Development Network (1 interviewee). CDN leads on innovation, creating CPD opportunities and sharing best practice. https://www.cdn.ac.uk/

\section{Key themes emerging from the interviews}

A number of common themes were identified across the interviews which are discussed below. These broadly concerned:

1. National identity

2. Positioning within the sector 


\section{The 'Skills Agenda' \\ 4. Relations of governance}

\section{National identity}

National identity emerged as a key mobilising theme both in interviews and policy documents. The distinctiveness of Scotland's approach is indicated through repeated use of phrases such as 'inclusive growth', 'inclusive economic growth', or 'inclusive and sustainable economic growth'. Colleges in Scotland are thus securely enrolled into Scotland's 'National Performance Framework' (Scottish Government,nd) which seeks to ensure that 'the benefits of economic growth, wealth and opportunities are fairly shared', playing to Scotland's cultural identity as rooted in social justice.

Further, Scotland seeks to establish the Nation as a player on the world stage through an explicit orientation to transnational organisations, principally the OECD. Thus, the strategic plan of the newly formed Enterprise and Skills Strategic Board (ESSB) positions Scotland as 'mid-table' in the OECD member country's productivity scale, using this to construct a 'performance gap' within which the policy desire to make Scotland 'the most entrepreneurial and innovative nation in the world' is legitimated (ESSB 2018, 7). Global comparison has become a key instrument of governance. No'voa and Yariv-Mashal $(2003,427)$ refer to this as an 'international spectacle', exerting control through deficit-driven performance criteria. The performance gap as policy driver is clearly evident in the ESSB strategic plan. However, in the Scottish context the positioning of Scotland as a separate nation and the ambitious claims made for its future standing serve to normalise the idea of Scotland as a viable sovereign state. In this scenario, the Scottish Nationalist Government seeks 'promotion of the identity that Scotland has world class colleges' (SG interviewee). 
In our interviews, the OECD was not the only transnational space within which the college sector was positioned in asserting national identity. The European Union emerged as a key point of identification for several of our interviewees. Thus, one interviewee spoke of Scotland's colleges as being 'well connected with Europe, less so with the rest of the UK' and as having more in common with vocational education systems in Europe than with other parts of the UK. This, Keep (2017) argues, is indicative of a radically different policy approach in Scotland underpinned by a coherent labour market strategy aligning skills, productivity and innovation to create an education and training 'system', in contrast to England's 'market or quasi-market spaces' (744). As one interviewee remarked:

It looks from a distance like a national system with a national accreditation agency...a national government, a national quality framework... It's got the elements that look broadly like what you would see if you were designing from scratch a national system. [italicisation indicates emphasised speech]

This of course was the 'look' that Minister, Mike Russell, was aiming for in playing his ONS reclassification hand: a coherent, rationalised and 'nationalised' further education sector giving the appearance of having been planned that way to set against the chaos of the freefor-all in England.

In doing this, Ozga and Grek (2009) argue that Scotland has sought to align itself within the 'European policy space' and that many of the reforms underpinning regionalisation, are in response to this European agenda. More pragmatically, O'Donnell et al, (2015) suggest that a coherent and recognisable vocational system has served Scotland better in securing European funding through the European Regional Development Fund and the European Social Fund. This alignment with Europe as a point of national identity, and national 
viability, underpins the opposition to Brexit by the minority SNP Scottish Government, a very live issue during the period in which we were interviewing (Jan-June, 2019).

\section{Positioning of colleges}

Positioning of the college sector was effected through the language used to describe further education in Scotland. Thus, all interviewees very deliberately referred not to 'FE colleges' but to 'Scotland's colleges'. This branding of the further education sector reinforces the coherence aimed at through regionalisation. The use of the language of 'Scotland's colleges' was justified by interviewees on the grounds that colleges in Scotland deliver not only further but also much higher education (though at time of interviewing this is in the main at sub degree level). This too was drawn on by one of our interviewees to position Scotland in relation to England, giving the sector 'clout and weight' when compared with England:

Certainly the traditional metropolitan English college is a...very different beast from a complicated regional multi campus Scottish district and suburban institution.

(This, it should be noted, presents a rather partial view of colleges in England which vary in size and complexity and also provide higher education.) The promotion of the sector outwith Scotland, however, was not reflected to the same degree at home in which colleges were positioned rather differently - as misunderstood and marginalised by government, and as secondary to universities. It has become something of a cliché to describe further education as the 'Cinderella' sector, yet despite dislike of the term in some quarters, this was used by one college principal to position colleges: 
And that old thing about colleges being the Cinderella sector, actually all that stuff is completely true. It's under-researched, under-understood, undervalued and underfunded and all of that.

The 'misunderstanding' of what colleges do was referred to by all three college senior management we spoke to particularly in relation to the socially and economically disadvantaged nature of communities typically served by colleges. It was argued that those charged with policy development might 'never have been near a college' and did not understand what colleges are about.

The narrative of marginalisation also underpinned another cliché in the literature that colleges are defined 'by what they are not' (Grummell and Murray 2015). Further education is 'Other', placing colleges in a 'vacuum-like position, defined by its absence and lack of being' (p.433). Scottish policy, however, has assiduously sought to counter this rhetoric and to create an included further education sector. Thus the SFC strategic plan (2015-2018) refers throughout to 'colleges and universities'. Moreover, the 15-24 Learner Journey Review (LJR; Scottish Government 2018a) calls repeatedly for greater collaboration and partnership between schools, colleges and universities in seeking to articulate a seamless 'lifelong' pathway for the learner. However, in doing this the college sector is still marginalised, positioned as a conduit delivering (disadvantaged) students to the sunlit uplands of the university sector or providing an 'alternative', and by implication less highly valued, route to learning for those whose 'learning needs may not be suited by university' (Scottish Government interviewee). The twin raisons d'etre of colleges - providing skills and promoting social inclusion - produces a tension. Gallacher and Reeve (2019) argue that a focus on access was a strategic response to a diminished vocational role for colleges as a 
result of a number of factors including the erosion of the manufacturing base in the 1970s and 1980s and increase in participation in higher education. Arguably, the resultant tension has served neither colleges nor the economy well, contributing to a continuing marginalisation of colleges in relation to universities and perpetuating a largely class-based bias against 'vocational' education. (Though in this Scotland is certainly not alone).

In policy terms, the blurring of the distinction between further and higher education which the language of 'Scotland's Colleges' produces plays well to the rhetoric of the Learner Journey which seeks 'articulation' between schools, colleges and universities. The success story of a college sector preparing underprivileged students for universities is, however, challenged by some uncomfortable truths. Despite attempts to ensure that articulation between college and university should mean 'no loss of time for the student' (SFC website) more than half of the students who progress to university via colleges repeat a level of study (LJR, Scottish Government 2018a, 16). The length of time taken to get a degree is thereby extended, increasing opportunity costs for these already disadvantaged students. Moreover, the universities these students progress to tend to be the newer post-1992 institutions while 'Scotland's ancient universities do significantly less articulation' (LJR, Scottish Government 2018a, 56). This has implications for subject choice and career entry. Gallacher (2017) refers to this progression route as 'diversion'. Thus the learner journey via college is rather more convoluted than that undertaken by the majority of students entering universities. Moreover, retention and completion rates for these students is lower than for those with direct entry. This is the rationale underpinning attempts by some colleges to seek taught degree awarding powers (tDAP), though the dwindling pool of young people and the funding of articulation which currently favours universities also makes this a strategically desirable move. 


\section{The Skills Agenda}

The focus on the young learner has accompanied a change in the type of provision offered with the perception of a wholesale stripping out of part-time and non-accredited courses in favour of full-time courses leading to recognised qualifications. There are indications that this policy is, to some extent, being reversed with a greater focus on the needs of 'older learners' as part of a subtle shift in emphasis from social inclusion to the 'Skills Agenda'. This was referred to by a number of our interviewees. The spin from government is that the focus on the young learner was a response to the economic downturn and the need to 'avoid the scarring effects of youth unemployment' (SG interviewee). Now this has been sorted attention is being turned to older workers. Already the phrase 'post-24 group' was becoming common during this phase of the research. The SFC Guidance (SFC 2018) to colleges reflects this shift and echoes the narrative spin that the needs of the young have now been met through the 'Developing Young Workforce' plan which is now 'in year six of the seven year plan' i.e. is nearly complete. This policy shift is also indicated in the SFC guidance on Outcome Agreements which states that:

The requirement for a national measure on young students has been removed and replaced with a national measure to cover all ages.

That the sector cannot afford to prioritise both groups was set out by the Auditor General in 2011 (Audit Scotland 2012):

In November 2011, Scotland's Colleges, the national body that represents the views of colleges, gave evidence to the Scottish Parliament's Education and Culture Committee. It said that, based on current cost models and configurations, if colleges 'took on one in four 16-19 year olds not in employment, education or training, and continued to service 18-24 year olds to the same level, there would be no funded 
provision left for older learners who make up over half of learners over 16 years of age.

Although this report is dated, the situation today is arguably no less acute following further squeezes to the sector. Recent increases in the college budget (2019) were almost entirely swallowed up by high wage costs arising from national bargaining and 'harmonisation' across the sector. While rates of pay may now exceed those in the English sector, which has also seen industrial unrest over low pay and worsening conditions, there are warnings that the increases in Scotland will lead to loss of jobs (TES, 2019) and signs that this may already be happening (Audit Scotland, 2019).

The phrase 'upskilling and reskilling' was used by all interviewees, and refers to the post-24 group (since presumably younger learners require in the first instance 'skilling'). Upskilling is the enhancement of existing skills, while reskilling refers to career change. This shifts the focus from 'articulation' within a 'seamless' education system (allied to the development of social capital), to alignment between education and industry. Our interviewee from the Enterprise and Skills Strategic Board spoke of the need for 'closer working between industry and education' in which both the 'customer' and the 'learner' are at the centre. This creates a tension since it is only possible for both to occupy the centre if their interests are commensurate, but this is not at all self evident. Boltanski and Thevenot's 'sociology of critical capacity' $(1999,2006)$ is useful in examining this dilemma. Boltanski and Thevenot (2006) argue that the need to distinguish between legitimate and illegitimate actions on the basis of critical justification is a fundamental human capacity. They have developed a 'sociology of worth' as worlds or orders providing a framework for such justification, The six orders of worth they list (recognising that this is not exhaustive) are: civic; industrial; domestic; market; inspired; and fame. The principles underpinning these orders are, 
- Civic: civic duty, the collective good.

- Industrial: efficiency, effectiveness, performance.

- Domestic: tradition, loyalty, hierarchy.

- Market: competition.

- Inspired: inspiration, originality.

- Fame: public opinion, judgement of others. (Annisette and Richardson 2011).

In this framework education and industry occupy different orders of worth which appeal to different paradigms of critical justification. The educational function belongs to the 'civic' order whose mode of evaluation is the collective good, while industry belongs to the industrial order whose worth is measured in terms of productivity and efficiency. These orders embody diverse rationalities and hence while each is legitimate they are not commensurable. In order to bridge these divergent rationalities artefacts or 'conventions' are required which secure compromise, reduce uncertainty, and hence make action possible. In the case of the alignment between education/industry 'skills' emerges precisely as the convention which does this. What are the implications of this compromise? Certainly, the possession of skills enhances the civic (and economic) standing of the worker but at the same time it reduces the value of education to the level of the provision of human capital.

Conversely skills, as a bridging convention, inherently links industry to education and hence productivity has tended to be seen in relation to (supply-led) qualification deflecting attention from other factors impacting on productivity (Payne 2009). It is perhaps worth pointing out, however, that Stark (2009) contra Boltanski and Thevenot, regards bridging conventions as creating a productive dissonance that drives innovation. 
In this respect, Keep (2014) highlights an interesting distinction between Scotland and England. Keep points to data indicating that while Scotland 'out performed' England in terms of degree/subdegree level qualifications, little benefit of this was seen in GDP. From this the Scottish Government (2007) concluded that existing skills were not being used effectively in the workplace and hence that more effort should be made to address the demand side of the skills equation. That this remains an issue is backed up by McDonald and Kenny (2019) who state that 'there is a degree of mismatch between the supply and demand of skills and qualifications in Scotland' (14). The ESSB too underlines the importance of developing a more demand-led skills system 'that better responds to the current and future skills needs of employers and individuals' (ESSB 2018, 26), in particular flagging up the importance of 'meta skills' ('self-management, social/emotional intelligence and innovation skills'), which will be needed even in an era of increased automation.

This drive to increase 'economic pull' is embedded in current SFC guidance which requires colleges to show in return for funding 'evidence of how labour market demand is reflected in the college's provision'(SFC 2018). The SFC also seeks to enhance skills utilisation through encouraging innovation:

Our colleges also have a role to play in stimulating innovation through their close links to business and industry, particularly small and medium sized enterprises (SMEs), which predominate in the economy in Scotland. (SFC Strategic Plan 2015). This promotes, as Keep $(2014,260)$ notes, a 'bottom up' role for colleges in supporting workplace innovation through college/industry links. (Universities, by contrast are seen as adopting a 'top down' approach in relation to knowledge exchange.)This supports the idea of a role for colleges as civic anchors in their locality through the creation of 'sticky capital'. 
However, economic pull also requires SME to recognise, and make use of, the expertise present in colleges which at present does not appear to be the case (Culkin 2016).

The attention now being paid to upskilling and reskilling, which might reflect the changing demographic of an ageing workforce as much as the priorities of industry, could prompt a return to part-time, flexible, short courses in the pursuit of 'just in time learning' to better meet the needs of industry. Indeed, one of our interviewees spoke of the possibility of the return of night classes and said,

We cannot afford to send people to university or go through four years, because by the time they get into the workplace their skills are redundant. So there needs to be a more flexible work based system that will allow for courses which can be delivered and get skills into the workplace much more quickly.

The pre-eminence paid to the skills agenda may prove beneficial to colleges. Indeed, one of the college principals we interviewed neatly overturned the knowledge/skills binary which has hitherto privileged knowledge, referring to the 'bankrupt' knowledge economy and the rise of the 'skills economy'. If so, the current moment is propitious for colleges if they can rise to the entrepreneurial challenge.

\section{Relations of governance}

The governance framework for colleges in Scotland is rather fragmented. Indeed, the ESSB has been set up expressly to ensure 'hard alignment' between the various enterprise agencies and organisations concerned with the wider governance of the sector. In particular, the ESSB sits over the SFC, Skills Development Scotland (SDS), Scottish Enterprise, Highlands and Islands Enterprise, and the more recently formed South of Scotland Economic Partnership. The function of the ESSB is to provide a forum enabling collaboration and 'partnership' 
between these agencies coordinated through the skills agenda as one of four key drivers (or 'missions') for increased productivity which also includes: Business models and workplace innovation; Business creation and growth; and exports.

Under the aegis of the ESSB 'skills' as a bridging convention is to be operationalised through a joint forum of representatives of SFC and SDS 'to create a seamless, one system approach for learners, employers and the economy' (ESSB 2018, 29). This will require the SDS and SFC to appoint a Director of Skills Alignment and Planning, supported by a team drawn jointly from SDS and SFC (Scottish Government, Letter of Guidance to SDS 2018b) working in close collaboration and partnership. Partnership is a key concept in the third-way ideology that underpins the SNP government's policies, but it is not unproblematic. Cardini (2006, 396) describes it as a 'magic concept' which evokes comforting ideas of networking, collaboration and trust. In the normative discourse of partnership the presence of conflict is under-recognised and certainly undertheorised; dominant patterns observed in partnerships are frequently hierarchical and agonistic rather than coordinating (Davies 2004). Though partnership is seen by policy-makers as a panacea, one of our interviewees used the term 'shadow boxing' to describe the uneasy relationship between these bodies.

The SFC however, as the main funder of colleges, remains the most direct route of governance between colleges and government. The SFC sets out its core aims as 'caring' for colleges and universities. So used have we come to the discourse of performativity that the use of the term 'care' is dissonant. Care connotes 'concern for' but goes beyond this to encompass 'affective attachment', defined by Fisher and Tronto $(1990,40)$ as 'everything that we do to maintain, continue and repair "our world" so that we can live in it as well as possible'. However, despite the feminine associations, it also strikes a note of paternalism: those cared for adopt the position of patients rather than agents. In relation to colleges, this paternalism is manifest in their relation of dependence on the SFC, and the requirement that 
colleges relinquish any surplus to Arms Length Foundations. Our interviewee from the SFC argued that this made little material difference to colleges - large capital investments, for example, would never have been funded from operating surpluses and even under previous arrangements all borrowing had to be approved by the Minister- but the interviewee did concede that in the longer term this might have a 'behavioural effect' damping entrepreneurial spirit.

Care includes ensuring the sustainability of the sector overall and in supporting institutions to remain solvent. Thus, the relationship of care diverges significantly from the situation in England in which the insolvency regime (introduced in 2019)means that, in effect, colleges will no longer be bailed out by exceptional financial support loans (Association of Colleges, nd). The relationship of care was also drawn on in positioning the SFC in relation to the newly formed Office for Students in England:

[what] particularly distinguishes us from the likes of the new Office for Students is that we are expected by the Scottish government to oversee, sustain, support the financial and governance health of our institutions.

The adoption of an ethic of care does not, however, specify how this care should be manifest in governance relations. And a clear tension is revealed in the competing discourses evident in SFC documentation in which constructs associated with care - 'support', help', 'nurture', sit alongside industrial notions of efficiency ('Quality Assurance', 'targets', 'performance'); the market forces of demand ('responding to skills needs'); and the civic requirements for the collective good ('promoting equality and diversity'). These competing discourses are aligned within the Outcome Agreement, introduced following the Griggs Report in 2012-13, negotiated between each regional entity and the SFC. 
OAs are a form of performance agreement (PA), in use in many countries in Europe and globally (de Boer and Jongbloed 2015), again reinforcing Scotland's alignment with the European policy space. Performance agreements set out the goals an institution agrees to commit to over a given time period. PAs may provide a number of functions: (1) to enable institutions to strategically position themselves; (2) to improve strategic dialogue between institutions and government; (3) to improve core activities; (4) to increase efficiency; and (5) to measure performance. They range from legally binding (e.g. in Finland) to 'softer' arrangements which carry no penalties for failures to achieve. De Boer and Jongbloed characterise the Scottish system as principally concerned with the second of these, improving strategic dialogue, which includes a requirement to align with the needs of learners, employers and the economy (SFC, 2019). However, there is evidence of a shift towards the harder end of the spectrum in the current iteration of the SFC strategic plan. This shift from 'care' towards performativity is flagged up in the Ministerial Letter of Guidance to the SFC for the period 2019-2020 (Scottish Government 2018b) and subsequently manifest in the SFC guidance (2018) under the construct of 'intensification' which emphasises the need for 'a clear line of sight' between Scottish Government investment and the delivery of desired outcomes. Intensification embraces a number of euphemisms: more 'ambitious' targets; 'enhanced' accountability; and 'incentivised' improvement. Alongside this, there are references to failure which will have implications for future funding and may even require monies to be recovered. This shift towards a more contractual relationship with increased monitoring indicates a reduction in trust and a concomitant rise in transaction costs, arguably placing an additional burden on an already stretched sector. It is therefore interesting to compare this with the speech given by Lord James Douglas-Hamilton, then Minister of Education in the Scottish Office, in 1992 at the launch of incorporation who said, 
We believe that the achievement of quality is best met by devolving the responsibility for quality to college level...The opportunity is there for FE colleges over the next decade to develop as mature institutions of high quality, as have many of our HE institutions. (Douglas-Hamilton 1992)

\section{Conclusions}

A number of themes emerge from this analysis and deserve comment since all have implications which extend beyond Scotland. The declaration by the ONS that colleges in the UK did not meet NPISH criteria produced a polarising moment which has contributed to farreaching changes and led to policy divergence within the UK. England responded by adopting a market-oriented approach conforming to a classic neoliberal model (Peck and Tickell, 2002) and now has a range of providers of training, including private companies, competing alongside colleges. The logic of the market is carried forward in the introduction of the insolvency regime, thereby creating a situation in which colleges are allowed to fail. Through reclassification, Scotland has taken a very different route imposing far greater centralised control of FE to create a recognisable and coherent national 'system' (Keep, 2017). This conforms to the 'Scottish Approach' (Cairney 2016) to policy and public service delivery in which policy outcomes are integrated into the National Performance Network and its associated objectives and outcomes.

Scotland's colleges are thus protected from the extremes of the market as currently operating in England but this does not come without cost. The previous autonomy enjoyed since incorporation in 1993 has given way to a sector tightly controlled from the centre. Scotland's colleges are enrolled into a complex web of governance largely operationalised through OAs. This is indicative of Porter and Craig's (2004) 'inclusive liberalism' based on a 
performativity which masquerades, not so much as partnership, but as paternalism (this is perhaps what distinguishes the 'Scottish Approach' from third-way Blairism). The sector now faces 'intensification' of targets and performance monitoring in return for a certain level of fiscal protection, which will certainly be needed in the current climate (Scottish Government 2019).

This attempt to create coherence is, however, frustrated by the persistent underlying tensions which accompany the 'skills agenda'. Skills have here been conceptualised as bridging Boltanski and Thevenot's (2006) civic and industrial realms requiring an uneasy compromise between the aims of education and the drivers of industry. Incommensurability between these realms produces recalcitrance which hinders attempts to produce 'alignment'. Scotland's colleges are charged with enhancing social inclusion and meeting the needs of industry, while at the same time they are marginalised and positioned as Other with respect to universities. Changing this requires a conceptual shift on the part of colleges, potential learners, and other stakeholders. Colleges need to divest themselves of their romantic image (in being positioned as 'Other' colleges are themselves culpable) so that they are perceived not as places for social remediation and second chances but as a first choice for all. This requires a certain amount of upskilling and reskilling on the part colleges. It also requires significant investment in the estate on the same scale as has happened in universities (Audit Scotland 2019).

Political uncertainty, industrial unrest, underinvestment and confusion over aims creates a toxic mix, presenting a series of challenges which will need to be addressed if the sector is not to become, in the memorable words of one of our interviewees 'a basket case'. In Scotland, the logic of paternalism means that a large part of the responsibility for this lies beyond colleges themselves, yet colleges cannot afford to be passive. Colleges will need to adopt an entrepreneurial spirit to meet the challenges ahead, not least to create a vibrant sector that reflects the aspirations they hold for their own learners, but this is precisely the 
attribute that being 'care-experienced' may compromise. Indeed, the Auditor General reports (Audit Scotalnd, 2019) that colleges are becoming increasingly reliant on government funding with significant falls in commercial income and concomitant reductions in funds held in Arms Length Foundations. In addressing this the quality of college leadership, and especially of governance at the college level, will be critical in navigating ambition and risk. Some of our interviewees suggested that the differences between further education in Scotland and England had led to a lack of engagement across the border. It is clear that much can be learned by developing closer relationships but this needs to be based on greater knowledge of how policy contexts impact on leadership and governance of colleges.

\section{Acknowledgements}

We would like to acknowledge the helpful comments of a reviewer of this paper. We also thank the participants in the study.

The work was supported by the Economic and Social Research Council (Grant Number: ES/R00322X/1).

\section{References}

Annisette, M., and A.J. Richardson. 2011. "Justification and accounting: Applying sociology of worth to accounting research." Accounting, Auditing and Accountability Journal, 24(2): 229-249.

Association of Colleges. The new college insolvency regime.https://www.aoc.co.uk/news/the$\underline{\text { new-college-insolvency-regime }}$ 
Audit Scotland. 2010. The role of boards.https://www.auditscotland.gov.uk/docs/central/2010/nr_100930_role_boards.pdf

Audit Scotland. 2012. Current finances, future challenges. https://www.auditscotland.gov.uk/uploads/docs/report/2012/nr_121018_college_overview.pdf

Audit Scotland. 2013. Scotland's colleges 2013.http://www.auditscotland.gov.uk/uploads/docs/report/2013/nr_130829_scotlands_colleges.pdf

Audit Scotland. 2019. Scotland's colleges 2019.https://www.auditscotland.gov.uk/report/scotlands-colleges-2019\#andgid=1andpid=1

Boltanski, L., and L. Thevenot. 2006. On justification. economies of worth (C. Porter Trans.). Princeton, NJ.: Princeton University Press.

Boltanski, L., and L. Thévenot. 1999. "The sociology of critical capacity.” European Journal of Social Theory, 2(3):359-377.

Cairney, P. 2016. The 'Scottish approach to policy making': Implications for public service delivery. Paper to Workshop: Leading Change in Public Services' Queen Margaret University, 13th June 2016.,

Cardini, A. 2006. "An analysis of the rhetoric and practice of educational partnerships in the UK: An arena of complexities, tensions and power". Journal of Education Policy, 21(4): 393-415.

Culkin, N. 2016. "Anchor institutions and regional innovation systems for supporting micro and small businesses." University of Hertfordshire, Research Publications, https://uhra.herts.ac.uk/handle/2299/17743 
Davies, J. S. 2004. "Conjuncture or disjuncture? An institutionalist analysis of local regeneration partnerships in the UK". International Journal of Urban and Regional Research, 28(3): 570-585.

de Boer, H., and B. Jongbloed. 2015. Reflections on performance agreements in higher education. Center for Higher Education Policy Studies, Universiteit Twente. https://ris.utwente.nl/ws/files/5606029/Pages\%20from\%20finansieringuh_rapport.pdf

Enterprise and Skills Strategic Board. 2018. Working collaboratively for a better Scotland.https://www.gov.scot/publications/working-collaboratively-better-scotland/

eurostat. Your key to European statistics.https://ec.europa.eu/eurostat/web/products-manualsand-guidelines/-/CA-15-96-001

Fisher, B., and J. Tronto, 1990. Toward a feminist theory of caring. In Circles of care. Edited by E. K. Abel, and M. Nelson .(pp. 35-62) New York: State University of New York Press.

Gallacher, J. 2019. New frontiers for college education: The challenges. In New frontiers for college education. Edited by J. Gallacher, and F. Reeve (pp. 3-18). London: Routledge.

Gallacher, J. 2017. "Higher education in the college sector: Widening access or diversion? questions and challenges from the Scottish experience." Journal of Education and Work, 30(7): 712-721.

Grek, S., and J. Ozga, J. 2009. "Governing education through data: Scotland, England and the european education policy space.” British Educational Research Journal, 36(6): 937952. 
Grummell, B., and M.J. Murray. 2015. “A contested profession: Employability, performativity and professionalism in Irish further education." Journal of Educational Administration and History, 47(4): 432-450.

Douglas-Hamilton, D. 1992. Mission and vision. Speech by Lord James Douglas-Hamilton, Minister for Education at the conference of the Association for Colleges at Moray College, 30.09.1992.

Keep, E. 2014. "The role of higher education within broader skills policies, a comparison of emerging Scottish and English approaches.” Higher Education Quarterly, 68(3): 249266.

Keep, E. 2017. “English exceptionalism re-visited: Divergent skill strategies across England and Scotland." Journal of Education and Work, 30(7): 741-749.

MacDonald, G. 2012. New college upheaval is on the cards. Times Educational Supplement, https://search.proquest.com/openview/dad945232e938ebd598eb7d9147cad14/1?cbl=36 $\underline{6363 \text { andpq-origsite }=\text { gscholar }}$

MacPherson, S. 2013. College regionalisation. SPICe Briefing 13/73, https://www.parliament.scot/ResearchBriefingsAndFactsheets/S4/SB_13-73.pdf

McDonald, E., and K. Richmond. 2019. Measuring Scotland's economic performance. Economic Commentary, 43: 1-24.

https://strathprints.strath.ac.uk/67584/1/FEC_43_1_2019_McDonaldERichmondK.pdf. 
McPherson, S. 201). ONS reclassification of colleges. SPICe Briefing, http://www.parliament.scot/S5_Education/Inquiries/20161216SPICeONSReclassificatio $\underline{n . p d f}$

Norris, E., and R. Adam. 2017. All change. Why Britain is so prone to policy reinvention, and what can be done about it. Institute for Government, https://www.instituteforgovernment.org.uk/sites/default/files/publications/IfG_All_chang e_report_FINAL.pdf

No'voa, A., and T. Yariv-Mashal. 2003. "Comparative research in education: A mode of governance or a historical journey?" Comparative Education, 39(4): 423-438.

Scotland's Colleges. Current finances, future challenges. 2012. http://www.auditscotland.gov.uk/docs/central/2012/nr_121018_college_overview.pdf

O’Donnell, P., Murphy, M., and Normand, C. (2015). The reinvigoration of scottish further education sector: An exploration and analysis of the recent reforms. Scottish Educational Review, 47(2), 59-77.

Payne, J. 2009. "Divergent skills policy trajectories in England and Scotland after Leitch". Policy Studies, 30(5): 473-494.

Peck, J., and A. Tickell. 2002. “Neoliberalizing space”. Antipode, 34(3): 380-404.

Porter, D., and D. Craig. 2004. "The third way and the third world: Poverty reduction and social inclusion in the rise of 'inclusive' liberalism". Review of International Political Economy, 11(2): 387-423. 
Scotland's Colleges. 2016. Code of good governance for Scotland's colleges.

https://www.cdn.ac.uk/wp-content/uploads/2016/10/Code-of-Good-Governance-forScotlands-Colleges-August-2016.pdf

Scottish Funding Council. 2011. SFC corporate publication .http://www.sfc.ac.uk/web/FILES/Corporate_publications_SFCCP022015_ScottishFundi ngCouncilStrategicPlan2015/SFCCP022015_SFC_Strategic_Plan_2015-18.pdf

Scottish Funding Council. 2015. SFC strategic plan 2015-2018. http://www.sfc.ac.uk/web/FILES/Corporate_publications_SFCCP022015 ScottishFundi ngCouncilStrategicPlan2015/SFCCP022015_SFC_Strategic_Plan_2015-18.pdf

Scottish Funding Council. 2018. SFC guidance for the development of college outcome agreements 2019-2020. http://www.sfc.ac.uk/web/FILES/guidance_sfcgd222018/SFCGD222018_College_Outco me_Agreement_Guidance_2019-20.pdf

Scottish Funding Council. 2019. Guidance for the development of College Outcome Agreements: 2020-21 to 2022-23. http://www.sfc.ac.uk/publicationsstatistics/guidance/2019/SFCGD202019.aspx

Scottish Government. 2007. Skills for Scotland. A lifelong skills strategy. Edinburgh: Scottish Government.

Scottish Government. 2011. Putting learners at the centre - delivering our ambitions for post16 education. Edinburgh: Scottish Government https://www.webarchive.org.uk/wayback/archive/20170701152640/http://www.gov.scot/ $\underline{\text { Publications/2011/09/15103949/15 }}$ 
Scottish Government. 2012. Reinvigorating college governance: The response to the report of the review of further education governance in Scotland. Edinburgh: Scottish Government. https://dera.ioe.ac.uk/14810/1/00396150.pdf

Scottish Government. 2012. Report of the review of further education governance in Scotland. ('Griggs report').Edinburgh: Scottish Government. https://www2.gov.scot/resource/0038/00387255.pdf

Scottish Government. 2018a. 15-24 learner journey review. Edinburgh: Scottish Government. https://www.gov.scot/publications/15-24-learner-journey-review$\underline{9781788518741 /}$

Scottish Government. 2018b. Scottish funding council letter of guidance 201819.http://www.sfc.ac.uk/web/FILES/AboutUs/SFC_letter_of_guidance_2018-19.pdf

Scottish Government. No date. National performance framework. https://nationalperformance.gov.scot/

Scottish Government/Scottish Funding Council. 2011. College regionalisation - proposals for implementing putting learners at the centre.

https://www.webarchive.org.uk/wayback/archive/20180516072850/http://www.gov.scot/ Publications/2011/11/e15115412/link

Scottish Parliament. 2014. Public audit committee 2nd report, 2014. Scotland's colleges 2013.http://external.parliament.scot/S4_PublicAuditCommittee/Reports/paur-14$\underline{02 w . p d f}$

Spours, K., A. Hodgson, P. Grainger, and D. Smith, D. 2019. Area-based reviews and their aftermath: Moving to a post-incorporation model for further education in England? 
Journal of Vocational Education and Training,

https://doi.org/10.1080/13636820.2019.1607534

Stark, D. 2009. The sense of dissonance. Accounts of worth in economic life. Princeton and Oxford: Princeton University Press.

Times Educational Supplement. 2019. Why better pay for college teachers means job losses. 19 June 2019. https://www.tes.com/news/why-better-pay-college-teachers-means-job-losses

Watson, C. 2020. Processes and practices of governing in further education colleges in the UK. Fegoverning.stir.ac.uk 